SCIENTIFIC REPORT

\title{
A randomised trial comparing $0.02 \%$ mitomycin $C$ and limbal conjunctival autograft after excision of primary pterygium
}

\author{
A L Young, G Y S Leung, A K K Wong, L L Cheng, D S C Lam
}

Br J Ophthalmol 2004;88:995-997. doi: 10.1136/bjo.2003.036830

Background: Mitomycin C (MMC) and limbal conjunctival autograft (LCAU) are two known useful adjuvants in the prevention of pterygial recurrence. This study was conducted to compare the outcome of these two treatments.

Methods: Prospective study on consecutive cases of primary pterygium (February 2001 to March 2002) randomised into two adjuvant groups: (1) intraoperative $0.02 \% \mathrm{MMC}$ for 5 minutes or (2) LCAU. Patients were followed for recurrence (defined as fibrovascular tissue invading the cornea $>1.5 \mathrm{~mm}$ ) and complications for a period of one year.

Results: 115 eyes in 114 patients who completed the study were randomised to receive MMC $(n=63)$ and LCAU $(n=52)$. There were 10 recurrences $(15.9 \%)$ in the MMC group and only one recurrence $(1.9 \%)$ in the LCAU group. There was a statistically significant difference in the recurrence rate between the two groups $(p=0.04)$. There were a total of three conjunctival cysts, three symblephara, one granuloma, and one dellen. No other visually significant complications were encountered in either group.

Conclusion: Although LCAU resulted in better one year success rates, it is technically more difficult and inapplicable in cases with previous limbal disturbance. Simple excision followed by MMC or LCAU are both safe and acceptable adjuvants for pterygium excision. Choice of adjuvant should be carefully made based on assessment of recurrence risk, local practices, and surgeon's expertise.

$\mathrm{P}$ terygium is a worldwide condition with a "pterygium belt" between the latitudes $30^{\circ}$ north and south of the equator. ${ }^{1}$ Pterygium is prevalent in Hong Kong, situated $22^{\circ}$ north of the equator. ${ }^{2}$ Ultraviolet radiation exposure is a major risk factor for its development. ${ }^{3}$

Simple excision carries a high recurrence rate ranging from $24 \%-89 \%{ }^{4}$ The addition of mitomycin C (MMC) of various concentrations has been reported to be effective in preventing recurrence. $^{5-7}$ However, MMC may result in devastating complications such as scleral necrosis and microbial infections. $^{8-10}$

Another alternative adjunct is conjunctival graft (CG). ${ }^{11-12}$ The limbal epithelium acts as a junctional barrier to conjunctival overgrowth and pterygium is considered to represent a "local limbal deficiency". ${ }^{13}$ The inclusion of limbal epithelium in conjunctival graft would restore the barrier function of the limbus. Recent studies have reported the effectiveness of limbal conjunctival autograft transplantation (LCAU) in the prevention of pterygial recurrence. ${ }^{74-16}$

Numerous studies comparing MMC with CG have been published. However, in the interpretation of results, it is important to compare the following: (1) primary or recurrent pterygia; (2) intraoperative or postoperative MMC; (3) simple CG or LCAU. Based on published results from previous studies, LCAU appears to be more effective in the prevention of pterygial recurrence. However, to the best of our knowledge, no prospective study has directly compared intraoperative MMC with LCAU for primary pterygium. We therefore set out to conduct a prospective randomised trial to assess the relative effectiveness these two adjuvants.

\section{MATERIALS AND METHODS}

Consecutive patients from February 2001 to March 2002 presenting for primary pterygium excision at tertiary referral cluster hospitals (Prince of Wales and Alice Ho Miu Ling Nethersole Hospitals) were recruited after full informed consent. Patients were randomised into two groups: group 1 (to receive intraoperative $0.02 \% \mathrm{MMC}$ ) and group 2 (to receive LCAU as adjuvants). The patients underwent detailed examination including visual acuity, intraocular pressure, extraocular movements, biomicroscopy, documentation of pterygial size, and dilated fundoscopy. All patients were followed for a minimum of one year and recurrence rates were assessed for 3, 6, 9, and 12 months. Exclusion criteria were collagen vascular disease or other autoimmune disease, pregnancy, ocular surface pathology or infection, previous limbal surgery, and double head pterygium.

The operations were performed under peribulbar anaesthesia. The excision consisted of the detachment of pterygium head and dissection of the body from the overlying conjunctiva. Subconjunctival pterygial tissue was excised to achieve as clear a margin as possible. In group 1, intraoperative MMC $(0.02 \%)$ was applied to the bare sclera for 5 minutes. ${ }^{5}$ The site of application was then thoroughly irrigated with at least $150 \mathrm{ml}$ of balanced salt solution. The conjunctiva peripheral to the excised pterygium was undermined and the edges sutured $2-3 \mathrm{~mm}$ from the limbus.

The surgical technique for group 2 was adopted from Rao et al. ${ }^{16}$ The area of bare sclera was measured after pterygium excision. A free conjunctival graft was harvested from the superior limbal region of dimensions approximately $1 \mathrm{~mm}$ larger than the recipient bed. The inferior margin of the graft was dissected towards the cornea to include part of the superficial limbus. Special precautions were taken not to damage the stroma in preventing any possible pseudopterygium at donor sites. The free graft was carefully transferred to maintain polarity of tissue and secured with interrupted 8.0 polyglactin episclerally.

Postoperatively, Pred Forte eye drops (Allergan, Irvine, CA, USA) four times daily and chloramphenicol ointment three times daily were used for 4 weeks for both groups. Recurrence was defined as fibrovascular proliferation invading the

Abbreviations: CG, conjunctival graft; LCAU, limbal conjunctival autograft; $M M C$, mitomycin $C$. 
cornea $>1.5 \mathrm{~mm} .{ }^{5}$ Student's $t$ test was used to analyse recurrence rates, and a p value less than 0.05 was considered significant.

\section{RESULTS}

The demographic and clinical details are summarised in table 1. A total of 167 eyes (94 MMC, 73 LCAU) in Chinese patients were initially recruited. However, 115 eyes (63 MMC, 52 LCAU) of 114 patients completed the study with a one year follow up. The two groups were clinically similar for age, sex, and pterygial size.

There were 10 recurrences $(15.9 \%)$ in the MMC groupone at 3 months, four at 6 months, two at 9 months, and three at 12 months (table 2 ). There was only one recurrence $(1.9 \%)$ in the LCAU group identified at 3 months and the difference in recurrence rates was statistically significant $(p=0.04)$. There were three conjunctival cysts (two MMC, one LCAU), three symblephara (two MMC, one LCAU), one granuloma (MMC), and one dellen (MMC). No scleral thinning, necrosis, or any other visually significant complications were encountered in either groups.

\section{DISCUSSION}

Mitomycin C is an alkylating, antineoplastic agent which prevents cellular division and replication by inhibiting DNA synthesis. Determinants of its effectiveness would include the stage at which MMC is applied and whether the sclera is covered with conjunctiva. Intraoperative MMC is preferred and the current regime of $0.02 \%$ MMC for 5 minutes has been found to be effective. ${ }^{5}{ }^{6}$ An alternative to improve outcome is the application of CG. ${ }^{6}{ }^{12}$ The inclusion of limbal epithelium in the CG would help to restore its barrier function. Recent studies on LCAU reported its effectiveness in the prevention of pterygial recurrence (0 to 12.5\%). ${ }^{74-16} \mathrm{Al}$ Fayez compared CG with LCAU (including primary and recurrent cases) and reported superior effectiveness for recurrent pterygia (no significant benefit for primary). However, one should note that no recurrence occurred in the LCAU group and the sample size was small. ${ }^{14}$ As LCAU may be more effective than CG, we therefore conducted the first randomised trial to directly compare the effectiveness of MMC with LCAU.

\begin{tabular}{|c|c|c|c|c|}
\hline & $\begin{array}{l}\text { MMC } \\
(n=63)\end{array}$ & $\begin{array}{l}\text { LCAU } \\
(n=52)\end{array}$ & $\begin{array}{l}\text { MMC+LCAU } \\
(n=115)\end{array}$ & p Value \\
\hline $\begin{array}{l}\text { Mean age } \\
\text { (years) }\end{array}$ & $\begin{array}{l}59.06 \\
(14.67)\end{array}$ & $\begin{array}{l}60.04 \\
(10.56)\end{array}$ & $\begin{array}{l}59.50 \\
(12.93)\end{array}$ & 0.68 \\
\hline $\begin{array}{l}\text { Áge range } \\
\text { (years) }\end{array}$ & $32-84$ & $39-81$ & $32-84$ & \\
\hline \multicolumn{5}{|l|}{ Sex } \\
\hline Male & 26 & 19 & 45 & \\
\hline Female & 37 & 33 & 70 & \\
\hline \multicolumn{5}{|l|}{ Laterality } \\
\hline Right' & 37 & 31 & 68 & \\
\hline Leff & 26 & 21 & 47 & \\
\hline $\begin{array}{l}\text { Follow up } \\
\text { (months) }\end{array}$ & $\begin{array}{l}16.17 \\
(3.47)\end{array}$ & $\begin{array}{l}16.73 \\
(4.01)\end{array}$ & $\begin{array}{l}16.43 \\
(3.71)\end{array}$ & 0.427 \\
\hline $\begin{array}{l}\text { Mean size } \\
\text { of pterygium } \\
\text { across limbus } \\
\text { in length }(\mathrm{mm})\end{array}$ & $\begin{array}{l}4.183 \\
(1.375)\end{array}$ & $\begin{array}{l}3.962 \\
(1.240)\end{array}$ & $\begin{array}{l}4.083 \\
(1.314)\end{array}$ & 0.372 \\
\hline $\begin{array}{l}\text { Preoperative } \\
\text { BCVA } \\
\text { (LogMAR) }\end{array}$ & $\begin{array}{l}0.4238 \\
(0.3644)\end{array}$ & $\begin{array}{l}0.3385 \\
(0.2514)\end{array}$ & $\begin{array}{l}0.3852 \\
(0.3199)\end{array}$ & 0.155 \\
\hline $\begin{array}{l}\text { Postoperative } \\
\text { BCVA } 1 \text { year } \\
\text { (LogMAR) }\end{array}$ & $\begin{array}{l}0.2873 \\
(0.3035)\end{array}$ & $\begin{array}{l}0.2327 \\
(0.2149)\end{array}$ & $\begin{array}{l}0.2626 \\
(0.2674)\end{array}$ & 0.278 \\
\hline
\end{tabular}

Results are shown as mean (standard deviation).

\begin{tabular}{|c|c|c|c|}
\hline & $\begin{array}{l}\text { MMC } \\
(n=63)\end{array}$ & $\begin{array}{l}\text { LCAU } \\
\text { ( } n=52)\end{array}$ & $\begin{array}{l}\text { MMC+LCAU } \\
(n=115)\end{array}$ \\
\hline 3 months & 1 & 1 & 2 \\
\hline 6 months & 4 & 0 & 4 \\
\hline 9 months & 2 & 0 & 2 \\
\hline 1 year & 3 & 0 & 3 \\
\hline Total & $10(15.9 \%)$ & $1(1.9 \%)$ & 11 (9.6\%) \\
\hline
\end{tabular}

In this series, the MMC recurrence rate was $15.9 \%$, in comparison with $38 \%$ reported by Chen et al ${ }^{12}$ and $10.5 \%$ by Manning et al with the application of $0.4 \mathrm{mg} / \mathrm{ml}$ for 3 minutes. ${ }^{11}$

Both of these studies compared MMC with CG. The higher rate of recurrence observed by Chen may be related to the postoperative MMC application with bare sclera technique. In addition, higher concentrations of MMC are associated with the potential for a higher rate of and more serious complications. ${ }^{511}$ No scleral thinning, necrosis, or any other visually significant complications were encountered in the current study. A direct comparison of trial results is difficult with the many variations in pterygium inclusion criteria ( simple, recurrent, or mixed), dosages of MMC, definition of recurrence, and follow up periods. In addition, the dissection and extent of clearance by surgeons with different levels of experience would further contribute to variations in recurrence rates. ${ }^{17}$

Chen et al reported the mean time to recurrence from 3.7 to 4.8 months and only $6 \%$ were noted after the sixth postoperative month. ${ }^{12}$ In contrast, $50 \%$ of our MMC cases recurred after the sixth postoperative month. However, our results were similar to previous reports that those who recurred were younger than the non-recurring patients (mean age of 47.10 (SD 12.48) years $v 59.06$ (SD 14.67) years). ${ }^{7}{ }^{12}$

Ma et al (postoperative MMC) and Sharma et al also compared MMC with CG but neither showed any statistical difference. ${ }^{18} 19$ The former applied historical controls for comparison whereas the number of cases was small in the latter. However, failure of these studies to show any difference between MMC and CG is consistent with $\mathrm{Al}$ Fayez reporting an advantage of LCAU over CG, and the results of our study reporting an advantage of LCAU over MMC.

Manning et al and Chen et al reported CG recurrence rates of $22.2 \%$ and $39 \%$ respectively. ${ }^{6}{ }^{12}$ The MMC and CG recurrences were similar in Chen's study. In contrast, Manning et al reported a higher recurrence rate in CG. On the other hand, a randomised trial by Mutlu et al comparing LCAU versus CG with intraoperative MMC in the treatment of recurrent pterygia did not reveal any difference in recurrence rates. ${ }^{7}$ It is possible that the lack of relative efficacy of LCAU may be related to the technique chosen to perform the original primary pterygium surgery, where the LCAU may have included tissue from a previously harvested CG site. In the current study, there was only one recurrence $(1.9 \%)$ in the LCAU group and the results are comparable with those published by Rao et al. ${ }^{16}$ However, this procedure is relatively more time consuming and skilful dissection of graft is required. Furthermore, in cases where the superior limbus is scarred (for example, glaucoma with trabeculectomy), an alternative site for harvest is required. ${ }^{20}$

The main limitation of this study is the default rate of $31.1 \%$ ( 115 of 167 eyes completed the study) despite multiple attempts to trace and call back patients for review. This may 
be related to the working age group and the reluctance of patients to return around the SARS (severe acute respiratory syndrome) period in Hong Kong. The default rate was similar for both MMC and LCAU.

In conclusion, LCAU resulted in better one year success rates in primary pterygium. Further study is underway to compare the outcome of MMC and LCAU in recurrent pterygia. Simple excision followed by MMC or LCAU both yielded acceptable results. The choice of adjuvant should be carefully made by assessing individual recurrence risk factors, local practice preferences, and surgeon's expertise.

\section{Authors' affiliations}

A L Young, G Y S Leung, A K K Wong, L L Cheng, D S C Lam, Department of Ophthalmology \& Visual Sciences, The Chinese University of Hong Kong, Prince of Wales Hospital, Shatin, Hong Kong, People's Republic of China

L L Cheng, Alice Ho Miu Ling Nethersole Hospital, Tai Po, NT, Hong Kong, People's Republic of China

Financial support: Supported in part by Action for Vision (AFV) Eye Foundation, Hong Kong

Financial and propriety interest: none

Correspondence to: Dr A L Young, Department of Ophthalmology \& Visual Sciences, The Chinese University of Hong Kong, Prince of Wales Hospital, Shatin, NT, Hong Kong; asmyoung@netvigator.com

Accepted 1 January 2004

\section{REFERENCES}

1 Cameron ME. Pterygium throughout the world. Springfield, IL: Charles C Thomas, 1965.

2 Karukonda SR, Thompson HW, Beuerman RW, et al. Cell cycle kinetics in pterygium at three latitudes. Br J Ophthalmol 1995;79:313-17.

3 Moran DJ, Hollows FC. Pterygium and ultraviolet radiation: a positive correlation. Br J Ophthalmol 1984;68:343-6.
4 Jaros PA, DeLuise VP. Pingueculae and pterygium. Surv Ophthalmol 1988;33:41-9.

5 Lam DS, Wong AK, Fan DS, et al. Intraoperative mitomycin $C$ to prevent recurrence of pterygium after excision: a 30 -month follow-up study. Ophthalmology 1998;105:901-4.

6 Manning CA, Kloess PM, Diaz MD, et al. Intraoperative mitomycin in primary pterygium excision. A prospective, randomized trial. Ophthalmology 1997; 104:844-8

7 Mutlu FM, Sobaci G, Tatar T, et al. A comparative study of recurrent pterygium surgery: limbal conjunctival autograft transplantation versus mitomycin C with conjunctival flap. Ophthalmology 1999;106:817-21.

8 Dunn JP, Seamone CD, Ostler HB, et al. Development of scleral ulceration and calcification after pterygium excision and mitomycin therapy. Am J Ophthalmol $1991 ; 112: 343-4$.

9 Dougherty PJ, Hardten DR, Lindstrom RL. Corneoscleral melt after pterygium surgery using a single intraoperative application of mitomycin-C. Cornea 1996; 15:537-40

10 Rubinfeld RS, Pfister RR, Stein RM, et al. Serious complications of topical mitomycin-C after pterygia surgery. Ophthalmology 1992;99:1647-54.

11 Manning CA, Kloess PM, Diaz MD, et al. Intraoperative mitomycin in primary pterygium excision. A prospective, randomized trial. Ophthalmology 1997; 104:844-8.

12 Chen PP, Ariyasu RG, Kaza V, et al. A randomized trial comparing mitomycin $\mathrm{C}$ and conjunctival autograft after excision of primary pterygium. Am J Ophthalmol 1995;120:151-60.

13 Tseng SC. Concept and application of limbal stem cells. Eye 1989;3:141-57.

14 Al Fayez MF. Limbal versus conjunctival autograft transplantation for advanced and recurrent pterygium. Ophthalmology 2002;109:1752-5.

15 Gris O, Guell JL, del Campo Z. Limbal-conjunctival autograft transplantation for the treatment of recurrent pterygium. Ophthalmology 2000; 107:270-3

16 Rao SK, Lekha T, Mukesh BN, et al. Conjunctival-limbal autografts for primary and recurrent pterygia: technique and results. Indian J Ophthalmol 1998;46:203-9.

17 Ti SE, Chee SP, Dear KB, et al. Analysis of variation in success rates in conjunctival autografting for primary and recurrent pterygium. $\mathrm{Br} J$ Ophthalmol 2000;84:385-9.

$18 \mathrm{Ma} \mathrm{DH}$, See LC, Liau SB, et al. Amniotic membrane graft for primary pterygium: comparison with conjunctival autograft and topical mitomycin $C$ treatment. Br J Ophthalmol 2000;84:973-8.

19 Sharma A, Gupta A, Ram J, et al. Low-dose intraoperative mitomycin-C versus conjunctival autograft in primary pterygium surgery: long term followup. Ophthalmic Surg Lasers 2000;31:301-7.

20 Wong AK, Rao SK, Leung AT, et al. Inferior limbal-conjunctival autograft transplantation for recurrent pterygium. Indian J Ophthalmol 2000;48:21-4. 